Kádár, Judit. "Republishing Pre-World War II Hungarian Women Writers After the Fall of Socialism." Hungarian Cultural Studies. e-Journal of the American Hungarian Educators Association, Volume 10 (2017) DOI:

\title{
Republishing Pre-World War II Hungarian Women Writers After the Fall of Socialism
}

\section{Judit Kádár}

\begin{abstract}
Immediately before and shortly after the collapse of socialism in 1989, a large number of private publishing houses were founded in Hungary. Some of them began their career by republishing the novels of selected popular Hungarian women writers of the preWorld War II era that had been banned following the Soviet occupation of the country in 1945. The lack of comprehensive literary criticism on the works of women authors drove the new publishers to rely on the so-called "oral canon" of collective memory, which had saved some of their names from oblivion. To grab the attention of prospective readers, the books selected for publication were provided with modern book cover designs, reflecting new, but still patriarchal values. After a brief overview of how prewar literature was censored after 1945, focusing on the editors' inevitable reinterpretation of the writings of Renée Erdős, Mrs. Kosáry Lola Réz, and Anna Tutsek through book cover designs, Kádár aims in this paper to survey in what ways and how successfully the re-editions of the novels by women writers have contributed to their inclusion in the literary canon since 1989.
\end{abstract}

Keywords: Banned Hungarian woman writers, Communist literary censorship, literary canon, book cover designs

Biography: Judit Kádár received her Ph.D. in Hungarian Literature from the Hungarian Academy of Sciences, Budapest. Currently she teaches American Literature and Twentieth-Century British Prose in the Department of English Studies at the Savaria Campus of Eötvös Loránd University in Szombathely. Her main field of research is nineteenth- and twentieth-century Hungarian women writers. She has published an anthology of twentieth century Hungarian women poets, Térdig születésben, halálban ['Up to Their Knees with Birth and Death'], a collection of literary criticism, Royal Flush. Kritikák a brit és amerikai prózairodalomról ['Royal Flush: Critical Essays on British and American Works of Prose'], and a monograph on pre-World War II Hungarian women writers Engedelmes lázadók ['Obedient Rebels']. kadar.judit@ sek.elte.hu

Although in the first half of the twentieth century more than a hundred women writers in Hungary aspired for financial and professional success and at least a dozen of them did succeed, after the Soviet occupation of the country in 1945, ending in the Communist takeover of 1948, almost all of their names and works fell into oblivion. Besides banning Fascist and Nazi books, the communist regime also stamped most of these women's writings 'en bloc' as lacking in social value and hence politically harmful, and made them inaccessible to readers. Soon postwar literary historians, basing their critique on the few prewar reviews of these women's books, 
Kádár, Judit. "Republishing Pre-World War II Hungarian Women Writers After the Fall of Socialism.” Hungarian Cultural Studies. e-Journal of the American Hungarian Educators Association, Volume 10 (2017) DOI:

which had condescendingly labeled them as pleasant, intellectually undemanding writings for women, what today might be disparagingly labeled "chick lit," classified pre-war women's writings as popular literature (Aradi 1943: 426). These literary historians were also toeing the line of the cultural policy of the governing Socialist Workers' Party, as popular literature intended for the petty bourgeois masses and for the bourgeois middle class was the branch of literature that the new political system aimed to eradicate. This repudiating attitude of what was deemed [petit] bourgeois literature of socialist cultural bureaucrats pervaded the chapter on preWorld War II "conservative" literature in the last book of the "official" six-volume A magyar irodalom története ['History of Hungarian Literature'] edited by Miklós Szabolcsi that was first published in 1966, although even by way of repudiation only three of the very many "nonprogressive" female writers of the period were considered worthy of even being named.

Thus, except those women writers who had expressed communist/socialist sympathies before 1945, almost all pre-war female authors were eradicated from the literary canon by having their books banned and their writings ignored in postwar literary histories, which resulted in the suppression of their very names for decades by cultural journalists in the mass media. (Needless to say, at the same time some male authors deemed politically dangerous, such as Sándor Márai and György Faludy, or the Catholic poet László Mécs, were similarly silenced.) Nevertheless, the memory of a number of bestsellers authored by women survived in a kind of unofficial "oral canon" that had been at least partly born out of antipathy to the political system. This oral literary canon preserved the names of three such writers: Anna Tutsek (1865-1944) was remembered because of the enormous prewar popularity of her seven-volume "Cilike-series" about a lively girl's adventures, who is an imprudent adolescent in the first volume and a giddy grandmother in the last book; Renée Erdős (1879-1956), who was appreciated as the author of outspoken novels dealing with female sexuality; and that of Mrs Kosáry Lola Réz (1892-1984), who was famous as an author of books representing liberal and conservative values, as well as a translator. She translated into Hungarian Margaret Mitchell's Gone with the Wind and the novels of the Nobel Prize winner Pearl S. Buck, both enormously popular in interwar Hungary.

Surprisingly, the writings of Tutsek, Erdős, and Mrs Kosáry were not banned in the ordinary way on indexes of prohibited books. Based on the armistice agreement between the Allies and Hungary signed in Moscow in January 1945, the Provisional National Government of Hungary set up a committee to compile a list of Fascist, anti-Soviet, and anti-democratic books and press publications that were to be confiscated from printing houses, book publishing companies, booksellers, public libraries, school libraries, and individuals. Between July 1945 and November 1946, the committee, which operated under Soviet control, issued four lists encompassing approximately 4,000 books and 260 newspapers and periodicals (Sipos 2007). Along with books by Mussolini and Hitler, the work of a popular right-wing female writer, Cecile Tormay (1867-1937), who had been an iconic public figure of the Horthy era, were on the lists. These included Tormay's anti-Semitic Bujdosó könyv and its English and French versions (An Outlaw's Diary, London, 1923, Le livre proscrit, Paris, 1925) and some of her Fascistsupporting publications. However, the names of the other famous female writers were not put on any of the lists. The withdrawal of their books, including even Mrs Kosáry's translations, was due rather to the decisions of intimidated librarians and booksellers. This "csendes index" ["silent index'] worked so effectively that until the late eighties their writings were made available only to scholars with special permission to access the "Restricted Section" of the National Széchényi 
Kádár, Judit. "Republishing Pre-World War II Hungarian Women Writers After the Fall of Socialism.” Hungarian Cultural Studies. e-Journal of the American Hungarian Educators Association, Volume 10 (2017) DOI:

Library. After then, the use of the so called "zárt anyag" ['locked away material'] gradually became unrestricted, paving the way for reissues.

Even preceding the first free elections in 1990, as the Communist regime had gradually been losing power, new profit-oriented private publishing houses began to emerge. Some of these new publishing houses aimed at gaining moral and/or financial profit by beginning to publish from the works of formerly banned authors. Selection from the vast bulk of books published before 1945 was hindered by the lack of both prewar and postwar comprehensive literary criticism on the works of women authors. The new editors could lean only on the unreliable "oral canon" not less influenced by political considerations than the official one. Allegiance to the memory of banned books and writers indicated a secret opposition to the political system. Therefore, the aesthetic judgment of those women writers who were known in the first half of the twentieth century was undermined by the patriarchal prejudices before World War II, and by the political prejudices of the "official" and the "alternative" canons since 1945. These preconceptions have influenced evaluation of the three authors. Until now, the criteria and categories of reappraisal have not yet been evaluated fully. The first book that attempts to create a new taxonomy, László Kemenes Géfin's and Jolanta Jastrzębska's Erotika a huszadik századi magyar regényben 1911-1947 ['Eroticism in the Twentieth Century Hungarian Novel 19111947'] was published in 1998. This lack of evaluation made republishing a risky enterprise at the dawn of the new political era. Whatever their aims may have been, the success or failure of the new publishing houses had an unavoidable impact on the reappraisal of women writers.

Although, in elaborating their publishing program, the new companies could not rely on literary analyses, they could take into account the gradual changes in censorship policy even during the period of Soviet control and the achievements of state-owned publishing houses in broadening the boundaries of restriction previous to 1989. The foundation of private companies was preceded by the attenuation of censorship: the change began with the death of Stalin in 1953 , which was immediately followed by the elimination of the "silent" publication ban on some books, such as the poetry of László Mécs which became publishable in the very same year. However, in the sixties and seventies, even though some works by previously banned writers began to be published this did not include prewar literature written by the above named women authors. At that time the list of banned writers was shortened only slowly; in this respect, the censorship policy of neighboring Soviet bloc countries was more liberal. Mrs Kosáry Lola Réz's translation of Gone with the Wind was republished by two Hungarian-language book publishing companies, first in Yugoslavia in 1965, then in Romania in 1976 before it was reissued in Hungary in 1986. From the beginning of the eighties, censorship in Hungary also steadily decreased: in this phase, a few state controlled publishing houses started reissuing books or translations by female authors who had not been completely squeezed out of the official canon, namely, those writers whose names had been mentioned already in the sixties with some recognition in the official History of Hungarian Literature and who were mentioned from then onwards in the works of scholars otherwise loyal to socialism (Simon 1990: 91-93).

At this time, while the books of Cécile Tormay remained strictly banned, some of the novels by another female author, Irén Gulácsy (1894-1945), were gradually allowed a place at the margin of the official canon. Gulácsy's most acclaimed work, Fekete völegények ['Black Grooms'] (1927), a historical novel set in sixteenth-century Hungary, was published by Szépirodalmi Kiadó ['Fiction Book Publishing House'] in 1985. The work reinforced the idea that over the course of Hungarian history its failures have always been caused by foreign 
Kádár, Judit. "Republishing Pre-World War II Hungarian Women Writers After the Fall of Socialism.” Hungarian Cultural Studies. e-Journal of the American Hungarian Educators Association, Volume 10 (2017) DOI:

aggression and internal discord, an idea that had continuously been part of the unofficial oral canon. One year later Szépirodalmi also reissued Gulácsy's Nagy Lajos király ['King Louis the Great'], a dramatic history of King Louis the Great of Hungary, who it was generally believed had been able to turn the country into a medieval European power. In addition to Gulácsy's reputation in the unofficial canon, the most important criterion in the decision making of Szépirodalmi to publish those two historical novels might have been the fact that their nationalistic worldview was shared by many communist and socialist apparatchiks.

While the main aim in republishing both of Gulácsy's interwar historical novels might have primarily been the broadening of the range of publishable works, the covers, one of them decorative, the other plain, suggest that the editors were still afraid of censorship. They tried to meet the expectations of both the literary censors, who were of the opinion that only serious historical novels are publishable, and those of the readers, who wanted to purchase entertaining books. The simplified historical painting on the cover of Fekete völegények met the needs of prospective readers because it alluded to lightweight content, but the publishing house also tried to satisfy censorship with an accompanying scholarly essay by a renowned historian of the Hungarian Academy of Sciences. The plain cover of Nagy Lajos király targeted censors, because plain book covers would denote 'serious' content, and the majority of historical fiction, especially stories of Hungarian patriotism, were considered to be serious literature. However, the simple layout may have discouraged prospective buyers. Obviously, Szépirodalmi was not trying to market the latter book, but the lack of financial considerations would also demonstrate its excellence in the eyes of party bureaucrats (see Fig. 1.).
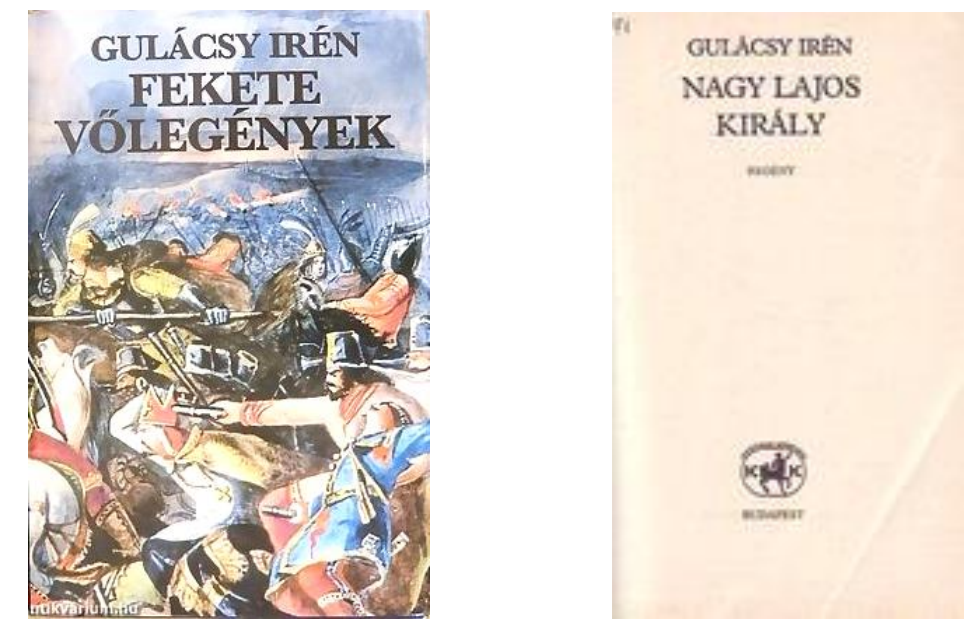

Fig. 1. Fekete vőlegények ['Black Grooms'] and Nagy Lajos király ['King Louis the Great'] by I. Gulácsy, published by the same publishing house in 1985 and 1986, respectively

The first reedition of a writing by a woman author who was commonly regarded as "strictly banned" occurred in 1987, at the time when the Communist government - to compensate for a decreasing state subsidy to the book industry - noticeably loosened censorship. Taking advantage of the opportunity, Közgazdasági és Jogi Könyvkiadó, a prestigious stateowned publishing house of legal and economics books, published a recipe collection embedded 
Kádár, Judit. "Republishing Pre-World War II Hungarian Women Writers After the Fall of Socialism.” Hungarian Cultural Studies. e-Journal of the American Hungarian Educators Association, Volume 10 (2017) DOI:

in a story entitled Katóka szakácskönyve ['Kate's Cookbook'] written by Anna Tutsek. Tutsek had been an idol for young middle class girls and wives before World War I, so her special cookbook soon became popular and reached two different editions, both from the year 1913. The choice of Közgazdasági és Jogi Könyvkiadó to issue the second eighty years later might have indicated the complexity of considerations for the new publishing houses, inasmuch as the two pre-war editions published in the same year differed significantly.

The recipes of the first 1913 edition (among them venison with orange sauce, Strasbourg foie gras and "American cake" - a chocolate cake with ground almond and rum) were inserted into a narrative about Katóka ['Kate'], a fifteen-year old orphan raised by her prototypically middle class grandparents. Katóka, after having sewn clothes from cast-offs for the children of the poor with her playmates, makes complicated gateaux and other expensive dishes with the help of her grandmother for her friends. The first edition of the cookbook-novel had been bound in plain blue cloth, showing a smiling young girl/woman with a wooden spoon in her hand and a traditionally equipped kitchen in the background, apparently aimed at upwardly mobile lower-middle class readers (Fig. 2.). Probably, the editors may have realized the incongruity of a teenager cooking fancy foods, so the second edition in 1913 was published without the novelistic narrative, thus changing the genre from a novel containing recipes to a simple cookbook. The editors replaced the figure of the obedient girl (teenage housewife?) of the cover with one who looks somewhat older and seems more likely a wife (and whose exaggerated zeal to serve family members may have induced some readers to reflect on women's new roles) (Fig. 3.). The anachronistic social structure reflected in the narrative parts and the obsolete image of women of the first edition no longer met the expectations of the publishing house in 1987, whose principal aim in republishing the work must have been to replace dwindling state support by profiting both from Tutsek's name and from the reviving public interest in cookbooks. Therefore the editors decided to produce a facsimile publication of the truncated second edition, leaving out the text that had been characteristic of Hungarian society before World War I but keeping all the luxurious recipes that few people could afford before the reintroduction of capitalism. (Cookbooks were particularly popular in the 1980s because many people read them to find out about foods that they could not eat in Hungary at the time, since many of the ingredients would have been prohibitively expensive or totally unavailable.) 
Kádár, Judit. "Republishing Pre-World War II Hungarian Women Writers After the Fall of Socialism." Hungarian Cultural Studies. e-Journal of the American Hungarian Educators Association, Volume 10 (2017) DOI:

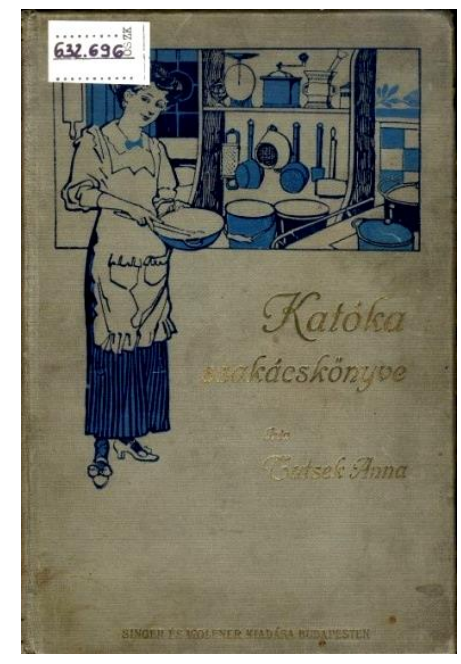

(Fig. 2.) The cover of the first edition

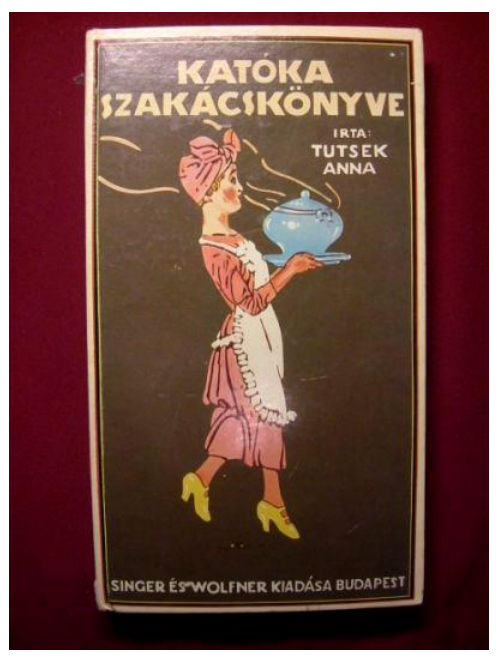

(Fig. 3.) The cover of the second and third editions

The Art Nouveau-like design of the 1987 edition of Katóka szakácskönyve seems quaint and ironic at the same time (Fig. 3.). While the readers might have found the housewife depicted as a submissive domestic servant of the household ridiculous, the delicious but unaffordable and/or unobtainable meals might have aroused their feelings of nostalgia toward the officially condemned prewar political system. In point of fact, Katóka szakácskönyve may have aroused interest as an indicator of the weakening political power and at the same time brought about its further weakening.

The first private publishing house, which experimented with publishing previously banned books by women writers in the last year of Communist rule was Garabonciás ['Wizard']. It published three volumes within five months: in July Mrs Kosáry's Álom ['Dream'], in September Erdős's A nagy sikoly ['The Big Scream'], and in November Tutsek's Cilike menyasszony lesz ['Cilike Becomes a Bride'], with subsequent novels by the three novelists published in the following year. Since the memory of these women writers had presumably been kept alive by the descendants of the prewar "Christian middle class" which favored conservative and paternalistic ideas, it is not surprising that the writers represent a specific ideology. Although women writers of the prewar era participated in almost all literary movements (symbolism, impressionism, realism, avantgarde, modernism), and their political ideas ranged from royalism to communism, each of these three selected authors held rather conservative political views, and used conventional narrative forms and features which account for the survival of their names.

Still, in spite of their apparent political and literary conservatism, Mrs Kosáry, Erdős, and Tutsek stood for women's emancipation to varying degrees. As the editor-in-chief of the magazine Magyar Lányok ['Hungarian Girls'] from 1895 until her death, Anna Tutsek was preoccupied with teaching young girls how to fit in the patriarchal society, but simultaneously she wrote short stories for Új Idők ['New Times'], the leading liberal-conservative literary magazine of the ruling classes, in which she condemned men, who having been contaminated by syphilis, married unknowing young girls without scruples, a case not infrequent in those days. Renée Erdős, who was born into a poor orthodox Jewish family and converted to Catholicism, 
Kádár, Judit. "Republishing Pre-World War II Hungarian Women Writers After the Fall of Socialism.” Hungarian Cultural Studies. e-Journal of the American Hungarian Educators Association, Volume 10 (2017) DOI:

also tried to appeal to the ruling elite by emphasizing the Christian conduct of her heroines, but unlike Tutsek, she was less successful in doing so. Although her books were widely read between the two World Wars, her fans dared open them only in secret, for Erdős's efforts were annulled by her early poems written at the turn of the century, which expressed female sexual desire openly. The oppressed sexuality of her submissive heroines that permeates her novels written after World War I could not obliterate the memory of her extraordinarily bold poetry. While Erdős gained a reputation as "the most erotic Hungarian woman writer," the name of Mrs Kosáry was kept alive by the collective memory during the Socialist era as a writer of juvenile books for Catholic readers. However, this categorization was also inaccurate: although she published popular novels for the youth that represented and advocated the Catholic norms of marriage, Mrs Kosáry professed herself a feminist even at the zenith of her career. In the 1930s, when she wrote a feminist historical novel sequence of four books, she was approaching the age of fifty. However, when the volumes of the tetralogy came out between 1942 and 1947, the fact that they belonged together and that the flow of novels had been an attempt to create a historical novel from a feminist point of view, went unnoticed.

The misinterpretation that missed the feminist elements of the writings of all three authors was mainly due to the contemporaneous reception of women writers: seen as undistinguished mass products of a gender-specific book industry, many of their books remained neglected by the critics. In the rare case when they were honored with short reviews, as Mrs Kosáry's above mentioned tetralogy, the reviews were based on superficial reading. In addition, the inconsistency and irresoluteness of these writers' views on women's rights and the conventional solutions offered by the endings of their novels contributed to their trials to support women's emancipation going unnoticed. However, Garabonciás' choice of Erdős's and Kosáry's books that portray young female protagonists who get married as the story develops but become dissatisfied with their subordinate status as wives and who then try to break out of this patriarchal system, suggests that Garabonciás realized that the submissive woman type was no longer the exclusive ideal for all women, at least not for young, educated urban dwellers. The editors recognized that these pre-war novels also raised new issues affecting women's roles. In republishing the works of Tutsek, the editors were now in search of grownup readers. They changed the original order of publication of her seven-volume series, starting with the second book because Cilike is only fourteen years old in the first volume and the story of a child would have mainly aroused the interest of young readers, while she grows into adulthood in the second one that could have interested somewhat more mature generations. However, the decision of Garabonciás to launch Tutsek's young adult novel in the sequence besides the novels by Erdős and Mrs Kosáry may have degraded the other two, not to mention the fact that the editors could have chosen among dozens of forgotten books representing women from a more progressive point of view.

The choice of Garabonciás Publishing House to bring out Mrs Kosáry’s Álom (originally published in a prestigious modernist literary journal, Nyugat ['West'] in 1921) as first in a series of republished pre-war women's fiction was not completely autonomous, for her descendants insisted on the republication of those volumes at the outset that had convinced contemporaneous critics of the writer's "conscious striving toward artistry," i.e. that the works that had been labeled "highbrow" (Wood 1995: x). The protagonist of Kosáry’s autobiographical novel, which takes place in a declining mining town in the Northwestern Carpathian region, is a young woman whose husband, getting tired of unexciting life in Selmecbánya, betrays her and moves to the 
Kádár, Judit. "Republishing Pre-World War II Hungarian Women Writers After the Fall of Socialism.” Hungarian Cultural Studies. e-Journal of the American Hungarian Educators Association, Volume 10 (2017) DOI:

capital city, Budapest. The major theme is the main characters' longing for the past and their homesickness for old-time Selmecbánya. The town, the birthplace of the writer, became part of Czechoslovakia following the First World War; it was a place to which, after her emigration to Hungary, she never returned. The theme of the novel reveals the real cause of the ban on the regionalist writer. Although she was a liberal-minded pacifist discarding the idea of border revision, the mention of territories that had been part of Hungary before World War I was a taboo in the Socialist period, and she was silenced because bureaucrats were afraid that her novels would have fomented irredentist sentiments. The editors of Garabonciás must have realized that the protagonist was a protofemist character. In all probability, they had been also aware of the significance of the setting for Hungarian readers, but they avoided highlighting the political aspects of the novel: the synopsis of the story featured on the book jacket underlines the growing self-consciousness of the protagonist and the process of her becoming a self-supporting New Woman, only to give up her autonomy and submit herself to the penitent husband who has returned to the mountain town at the end of the novel.

In the case of Erdős, Garabonciás unquestionably did choose the most infamous of her novels for republication in 1989, a book whose title, A nagy sikoly ['The Big Scream'] alludes to the unconscious expression of a woman's sexual fulfillment. The protagonist, Dora, a newly married girl from an upper-middle class family, who expects mutual understanding and autonomy in marriage, is cheated on by her landowner husband during their honeymoon. As a result, she becomes disillusioned with marriage and tries to lead an independent life within wedlock. However, after experiencing a kind of sexual satisfaction while listening to a musician playing the piano she develops a fear of her own sexuality. Dora's anxiety is reinforced by the suicide of a female friend who had admittedly enjoyed extramarital sex and by her Roman Catholic pastor's command to avoid divorce. Due to social pressure and her fear of sexual misbehavior she gives up her need for autonomy and surrenders herself to patriarchal power structures represented by her self-centered and over-confident husband by the end of the novel. According to this novel in 1923, there is no escape from the norms of the virtually feudalist ruling classes for bourgeois women. Patriarchal tradition always triumphs.

Tutsek's protagonist in Cilike menyasszony lesz (first published in 1909) embodies the prewar ideal of a submissive daughter and wife: she heartily accepts being governed by parents, adults, and then husband, never questions conventions and rules and remains somewhat thoughtless and childish even when she already has grandchildren. Despite the significant differences of tone and style of the three novels, these three protagonists belong to the same stock: unknowing, obedient young women/girls who do not wish to step out of the system of patriarchal control. Or if they do long for it, they remain, or return to it after an uncertain quest. On the whole, they represent the model behavior prescribed for the subordinated sex, Tutsek's Cilike the most unambiguously, Erdős's Dora with the most contradictions.

The didactic aim of the prewar publishers was reflected in the original covers of the books, especially in the case of Tutsek's writings, whose look had been inspired by Impressionist and Secessionist Art and depicted the heroines as female role models in beautiful natural environments (Figs 4-5.). Idyllic rural scenes of Hungarian artists (in contrast to the preference of decadent themes and urban settings of French or German painters) made their art especially well suited to express the ruling classes' ideals. In the absence of a strong bourgeoisie, the ruling elite was dominated by the landed gentry who spent most of their lives in the countryside (Szabadi 1979: 10). 

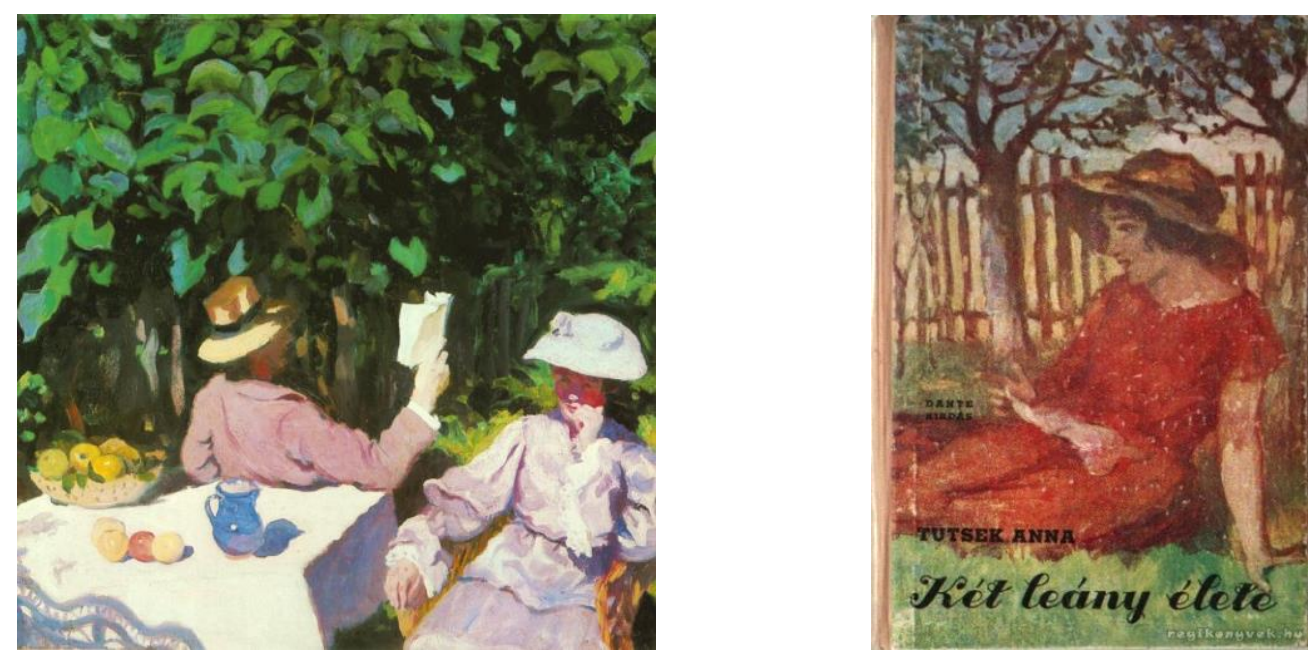

Fig. 4. Napos délelött [Sunny Morning] (1905) by the Impressionist painter Károly Ferenczy Fig. 5. Book cover of a novel written by Anna Tutsek, designed by András Biczó (1926)

By means of the fashionable styles at the time of their publication, the book covers of the prewar editions of Cilike menyasszony lesz presented Cilike as the exemplar of the well-to-do young lady of the propertied classes, maybe of the landed gentry the average readers may have liked to resemble. The artists also attempted to describe her figure in accordance with the expectations of emancipation that had taken place within the first three decades of the twentieth century, a transformation coming from the West, which feudalistic Hungarian society could not escape. Thus, on the covers Cilike was transformed from a country girl to an urban dweller, becoming more sexually attractive (Fig. 6.). On the cover of the first edition, which evokes plain-air painting, she looks like a nice but ordinary girl from a noble or bourgeois family. In another design, in Secessionist style, she is dressed as a married woman, glancing at the reader seductively. The Secessionist illustrator of a third graphic design presents her in a typical New Woman's dress, although in the novel Cilike is actually described as impatiently waiting for her mother's permission to let her wear long dresses. The designer of the fourth returned to nature to show an innocent girl in provocative, flimsy clothing (the publication year of the different editions was not indicated). The discrepancy between the conservative mentality of the books representing subordinate female behavior and the model of the relatively emancipated woman suggested by the wrappers widened volume by volume, but the book covers did not efface Cilike's most important characteristic feature: her innocence. 
Kádár, Judit. "Republishing Pre-World War II Hungarian Women Writers After the Fall of Socialism." Hungarian Cultural Studies. e-Journal of the American Hungarian Educators Association, Volume 10 (2017) DOI:
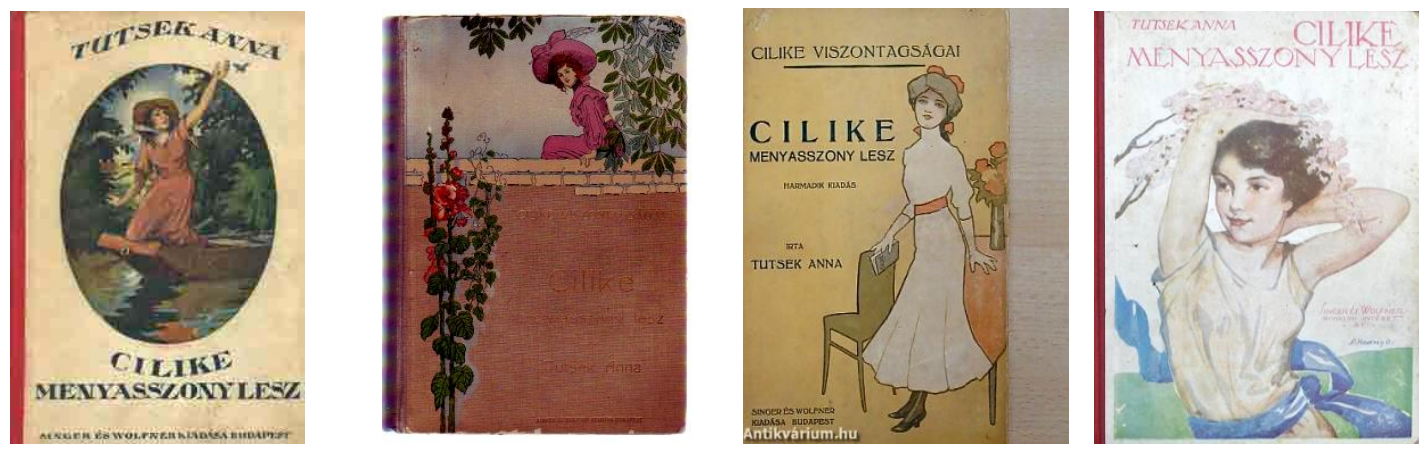

Fig. 6. Book covers of Cilike menyasszony lesz by A. Tutsek

By 1989 the social structure of Hungarian society had been transformed: the old ruling classes were swept away and women had long ago been forced to enter the labor market. Although prewar norms and values seemed to have disappeared, beneath the surface, patriarchal attitudes have acclimatized and endured changes. To counterbalance the presumably anachronistic idea(1)s of the novels it selected, Garabonciás Publishing House misled readers both by the jacket blurbs and by their stylized Secessionist designs (Fig. 7.). The blurbs of Mrs Kosáry's and Erdős's novels stress each protagonist's striving for self-conduct and leave their final surrender unmentioned. The highly-stylized book covers of Álom and A nagy sikoly emphasize the modernity of the heroines who wear fashionable hairstyle and thin dresses. It is noteworthy that homesickness, the major theme of Mrs Kosáry's book, is not indicated: the background behind the protagonist's figure is pink (symbolic color of a woman's dream) and blank. The two attractive women represent a new, nonetheless patriarchal ideal: they are provocative objects of male desire. Dependent Cilike could not have been portrayed as a femme fatale; both her dress and the floral motifs of the frame of the third cover are reminiscent of Art Nouveau style and accentuate her obsolescence. Her caricature-like female figure, expressing boredom, does not invite the readers to identify with her character. The cover indicates a certain detachment from the world of the novel.
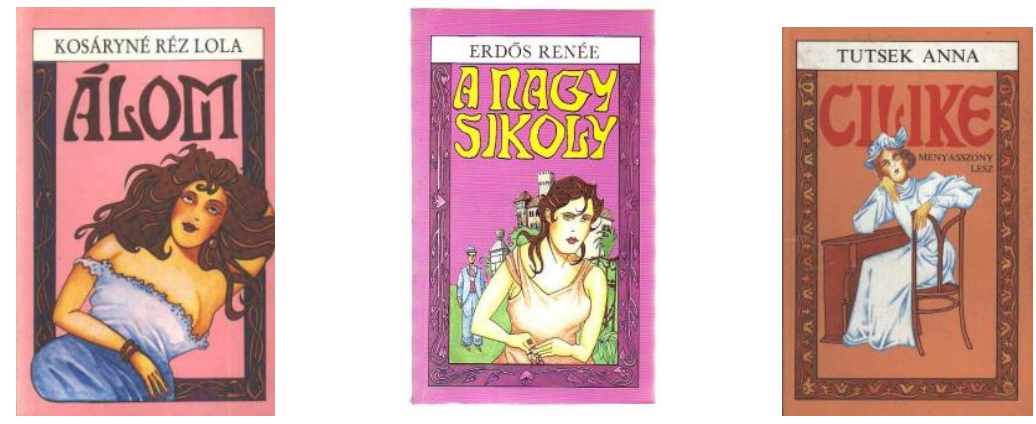

Fig. 7. The book covers of Álom, A nagy sikoly and Cilike menyasszony lesz, published in 1989 
Kádár, Judit. "Republishing Pre-World War II Hungarian Women Writers After the Fall of Socialism.” Hungarian Cultural Studies. e-Journal of the American Hungarian Educators Association, Volume 10 (2017) DOI:

While the prewar editions of the Cilike-series with constantly updated covers could have been successful because the protagonist exemplified norms that had been commonly accepted, the new book covers would not mislead the more emancipated "post-socialist" readers who would soon realize the irreconcilable antagonism of looks and content. Moreover, the tawdry book bindings and the paperback format suggested that the books belong to popular literature. Thus, consciously or not, the first private publishing house to reissue banned books of women writers confirmed both the prewar patriarchal prejudices-lowbrow literature by and for women - and the Communist conception-lowbrow literature for the masses - which had categorized these works as lacking literary value. Garabonciás's failed experiment in publishing these novels led to its bankruptcy within two years and it disappeared from the market in 1991. It was soon followed by other companies that ventured to publish non-institutionalized texts of banned women authors using the same method of modernizing the covers. Co-Nexus Publishing House issued a novel by Anna Tutsek in 1990, but that company also failed by 1992. Holnap Kiadó ['Tomorrow Publishing House'], founded in 1989, started to republish the Cilike-series in 2001, but its lack of success soon led to a change in policy and today it publishes classical music-themed books for children.

The reissuing of women writers who had only been on the 'silent index' might have been less risky than publishing an author who had been officially banned, yet Kvalitás Duó ['Quality Duo'], a publishing company of unknown owners, who did not want to be identified, founded in 1991 took on the task of rescuing from oblivion the name of Tormay. They published A régi ház ['The Old House'], a novel about the history of nineteenth-century Budapest that established her fame in 1914. Still, following its republication in 1991, the company disappeared from the book market. Nonetheless, some blatantly right-leaning publishing houses appear to have been more successful: Tormay's infamous Bujdosó könyv, that had been banned on the first book index in 1945, has been republished five times over the last twenty years, and with the support of rightwing intellectuals a statue was raised in honor of the writer in one of the central districts of Budapest in 2012.

Ultimately, republication of the most popular prewar women writers, Kosáry, Erdős, and Tutsek, did not lead to the acceptance of their books, not even as typical juvenile literature of a particular historical period. Readers did not show sufficient interest in what they probably perceived as outdated authors, and literary critics did not pay attention to what was perceived as popular literature. Thus, these first attempts to integrate banned women authors into the canon failed. The author of the only modern scholarly book on Hungarian juvenile literature, first published in 1990 revised the work for a new edition that came out in 2005, but the reissues of women writers in the intervening period had not influenced her opinion. Using a German expression, she still claimed that their (especially of Tutsek's) undeserving novels for girls are "typisch weiblich" (Komáromi 2005: 209), therefore not worthy of scholarly considerations. Although since that date a few literary historians have started to reconsider these works in the last few years, Agatha Schwartz's statement, that the Hungarian women writers were "rediscovered and re-appreciated" only "to some degree in the 1990s" seems to be still valid in the second decade of the twenty-first century (2008:174).

The attempts to reissue prewar women writers have not ceased. The volumes of Mrs Kosáry's feminist historical novel tetralogy have recently been published by Kráter ['Crater'], a publishing house that specializes in the reedition of works that represent conservative political ideology (Fig. 8.). Accordingly, the introductory essay (written by the author's grandson) 
Kádár, Judit. "Republishing Pre-World War II Hungarian Women Writers After the Fall of Socialism." Hungarian Cultural Studies. e-Journal of the American Hungarian Educators Association, Volume 10 (2017) DOI:

emphasizes the traditional role of obedient women subservient to their husbands in maintaining family and the nation, while the book covers show the main setting, the hills of Selmecbánya now belonging to Slovakia, the object of Mrs Kosáry’s homesickness.
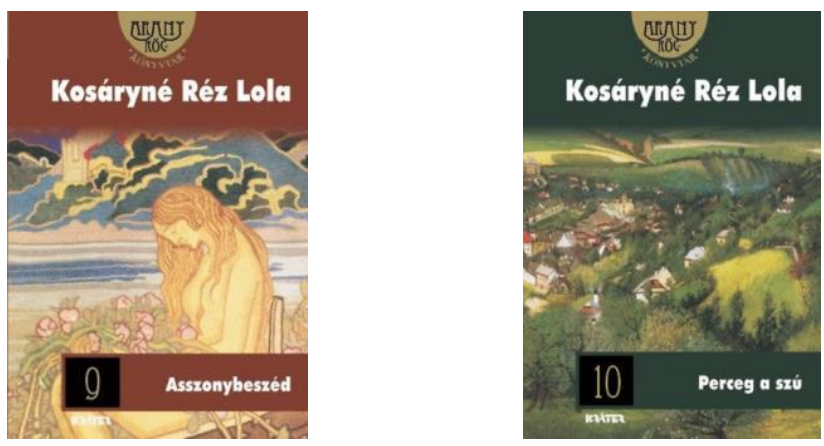

Fig. 8. The book covers of the first and second volumes of Mrs Kosáry's historical novel sequence, Asszonybeszéd ['Women's Gossip'] and Perceg a szú ['The Ticking of the Woodworm'] by painters Aladár Körösföi-Kriesch (1863-1920) and Tivadar Csontváry Kosztka (1853-1919)

The illustrations of the covers, the works of famous artists of Hungarian Secession and Postimpressionism, suggest that the publishing house now aims at presenting the books as highbrow literature. If they succeed, at least one of the three banned women writers, Mrs Kosáry, who professed herself a feminist until her death, might be included in a new canon that has neglected women writers until now.

This paper is a revised version of "Inclusion of Previously Banned Women Writers in the Hungarian Literary Canon after 1989, ” published in Studia Fenno-Ugrica Groningana 6, Maastricht: Shaker Publishing BV, 2011.

\section{Works Cited}

Aradi, Gábor. 1943. “Asszonybeszéd” ['Women's Gossip']. Sorsunk ['Our Fate'] 5: 426. Komáromi, Gabriella. 2005. Elfelejtett irodalom. Fejezetek a magyar gyermek- és ifjúsági próza történetéböl: 1900-1944. ['Forgotten Literature. Chapters from the History of 20th Century Children's and Juvenile Fiction: 1900-1944']. Budapest: Móra.

Schwartz, Agatha. 2008. Shifting Voices. Feminist Thought and Women's Writing in Fin-de Siècle Austria and Hungary. Montreal and Kingston: McGill-Queens University Press.

Simon, Zoltán. 1990. Az irodalom peremvidéke ['The Borders of Literature']. Budapest: Múzsák. 
Kádár, Judit. "Republishing Pre-World War II Hungarian Women Writers After the Fall of Socialism." Hungarian Cultural Studies. e-Journal of the American Hungarian Educators Association, Volume 10 (2017) DOI:

Sipos, Anna Magdolna. 2007. "Index librorum prohibitorum a demokratikus Magyarországon. (Könyvindexek 1945-1946)" ['Index librorum prohibitorum in Democratic Hungary (Book Indexes 1945-1946)'], Könyvtári Figyelö ['Library Monitor'] 3: 413-435. http://epa.oszk.hu/00100/00143/00064/68.htm

Szabadi, Judit. 1979. A magyar szecesszió müvészete [‘The Art of Hungarian Secession’]. Budapest: Corvina Kiadó.

Wood, Ruth Pirsig. 1995. Lolita in Peyton Place: Highbrow, Middlebrow, and Lowbrow Novels of the 1950s. New York: Garland. 